\title{
Susceptibility and Damage Cereals to Infestation Rhyzopertha dominica (F.) (Coleoptera: Bostrichidae) in Storage
}

\section{Kerentanan dan Kerusakan Serealia terhadap Infestasi Rhyzopertha dominica (F.) (Coleoptera: Bostrichidae) di Penyimpanan}

\author{
Hendrival, Dhea Afriani, Dewi Sartika Aryani \\ Department Agroecotechnology, Faculty of Agriculture, Malikussaleh University \\ Jl. Banda Aceh-Medan, Reuleut, Muara Batu, North Aceh, Aceh Province 24355 \\ Corresponding Email: hendrival@unimal.ac.id
}

\begin{abstract}
Rhyzopertha dominica is a primary pest which causes damages to stored cereals such as corn, grain, rice, wheat, sorghum, tubers, and starch-containing substrates and packaging made from wood. They not only cause losses in terms of quantity but also affect quality during storage period through their feeding activities. The aimed of this research to investigate the level of susceptibility and damage to cereals during the storage period by pest $R$. dominica. The cereals used in the study were sorghum, wheat, corn, rice grain, white rice, black glutinous rice, and white glutinous rice. The method used in this research was no-choice bioassay with variables observed: number of $F_{1}$ progeny, median development time and damage cereals. The results revealed that that different kind of cereals had a different level of susceptibility to infestation by $R$. dominica from moderate to susceptible. Sorghum, corn, rice, white rice, and white glutinous rice were classified as moderate, while wheat was classified as susceptible and black glutinous rice was moderate-susceptible. The highest losses were found in wheat, black glutinous rice, corn, and rice grain while the lowest were found in sorghum, white rice and white glutinous rice. The study showed that cereals that were susceptible may not stored for a long time to minimize the loss of grain weight.
\end{abstract}

Keywords: cereals, damage, susceptibility, susceptibility index, Rhyzopertha dominica

\begin{abstract}
ABSTRAK
Rhyzopertha dominica tergolong hama primer yang merusak serealia seperti jagung, gabah, beras, gandum, sorgum, umbi, dan substrat mengandung pati serta kemasan yang terbuat dari kayu. Kerusakan serealia selama penyimpanan meliputi kerusakan kuantitas dan kualitas yang disebabkan oleh hama $R$. dominica. Penelitian bertujuan untuk mengetahui tingkat kerentanan dan kerusakan serealia selama penyimpanan oleh hama $R$. dominica. Jenis serealia yang digunakan dalam penelitian terdiri dari sorgum, gandum, jagung, gabah, beras putih, beras ketan hitam, dan beras ketan putih. Metode uji tanpa pilihan dengan variabel yang diamati yaitu jumlah F1, median waktu perkembangan, dan kerusakan serealia. Hasil penelitian menunjukkan bahwa jenis serealia memiliki tingkat kerentanan dari moderat sampai rentan terhadap infestasi hama $R$. dominica. Serealia dari sorgum, jagung, padi, beras putih, dan beras ketan putih tergolong dalam kategori moderat, sedangkan gandum tergolong dalam kategori rentan, serta beras ketan hitam tergolong moderat-rentan terhadap serangan $R$. dominica. Tingkat kerusakan serealia seperti persentase serealia berlubang dan persentase bubuk serealia paling tinggi terjadi pada gandum, beras ketan hitam, jagung dan padi sedangkan kerusakan yang terendah yaitu pada sorgum, beras putih, dan beras ketan putih. Penelitian
\end{abstract}

Cite this as: Hendrival. Afriani, D. Aryani, D., S. (2019). Susceptibility and damage cereals to infestation Rhyzopertha dominica (F.) (Coleoptera: Bostrichidae) in storage. Jurnal Agro, 6(1), 57-65 https://doi.org/10.15575/4276 
menunjukkan bahwa serealia yang rentan tidak boleh disimpan dalam waktu yang lama untuk meminimalkan kehilangan berat.

Kata kunci: serealia, kerusakan, kerentanan, indeks kerentanan, Rhyzopertha dominica

\section{INTRODUCTION}

The lesser grain borer, Rhyzopertha dominica (F.) (Coleoptera: Bostrichidae) is one of the most major pests which causes damages to grains during storage period in many regions in the world (Mahroof et al., 2010; Edde, 2012; Chen \& Chen, 2013). This pest is classified as polyphagous insect and attacks a different kind of grains such as corn, grain, rice, wheat, sorghum, tubers, and other grains including starch-based substrates and some packaging made from woods (Edde et al., 2005; Edde, 2012; Ajaykumara et al., 2018). Rhyzopertha dominica is classified as a cosmopolitan insect pest from seeds in storage. This species can adapt well to dry conditions and easily spread from one storage area to another and create new infestations (Arthur et al., 2012).

Rhyzopertha dominica causes economic losses to stored cereals. The damage occurs due to weight deterioration by producing frass from damaged cereals, bad odors due to insect secretions and reduction of nutrient contents. These unpleasant results in cereals that are unfit for human consumption reduce essential amino acids and also reduce germination ability (Park et al., 2008; Ahmedani et al., 2009; Arthur et al., 2012). The larvae and adult stages are more dangerous so that the damage to stored cereal grains is greater than other pests (Vardeman et al., 2007). The two stages were spend most of their life inside the kernel, feeding on both the germ and endosperm, directly causing damages and changes in grain physicochemical properties
(Perišić et al., 2018). Quantitative damage such as weight loss by $R$. dominica has been reported in various types of cereal grains such as rice and sorghum (Chanbang et al., 2008; Chougourou et al., 2013).

This insect has a different preference for cereals which determines the level of cereal susceptibility in storage (Chougourou et al., 2013; Saad et al., 2018). The susceptibility dissimilarity occurs in various varieties of wheat and rice (Toews et al., 2000; Astuti et al., 2013). Several methods have been used to determine the susceptibility of stored cereals, such as measuring quantitative damage by calculating the percentage of frass and also insect biological parameters such as the level of development, fecundity, and life duration of adult insects (Chanbang et al., 2008). The information about the susceptibility of cereals to the infestation of $R$. dominica is still limited so that the researches on vulnerabilities of different types of cereals are needed. These researches are important due to its relation against population growth and quantitative losses to cereals during the storage period. This present study aimed to investigate the level of susceptibility and damage to cereals during the storage period by pest $R$. dominica

\section{MATERIALS AND METHODS}

The research was conducted at the Plant Pest and Disease Laboratory, Faculty of Agriculture, Malikussaleh University from June to August 2017. The cereals which were used in the study were sorghum variety Kawali, wheat variety Dewata, corn 
variety Bisma which all obtained from the Cereals Research Institute, Maros, South Sulawesi, Indonesia meanwhile rice plants and white rice Ciherang variety and Acehnese black and white glutinous rice were obtained from farmers in Baktiya District, North Aceh Regency.

\section{Mass-rearing and Infestation of $R$. dominica}

Mass-rearing of $R$. dominica was carried out in a plastic container with a capacity of $0.5 \mathrm{~kg}$ containing $200 \mathrm{~g}$ of red rice. 50 adults were infested into the container. The insects were reared for 5 weeks, and then 50 adults were separated from the media. The media were re-infested until $F_{1}$ progeny appeared. These adults were stored on new media. The separation of adults was done continuously until the number of fresh insects was obtained for the experiments. Each type of cereal used in the study as much as $100 \mathrm{~g}$ was put into a plastic container (height $12 \mathrm{~cm}$ and diameter 15 $\mathrm{cm})$. The aeration must be made at the lid of the plastic container (diameter $9 \mathrm{~cm}$ ) by covering the containers with gauzes. 10 fresh adult insects (aged 7 days) from the previous mass-rearing were re-invested into $100 \mathrm{~g}$ of grains and then stored during the study. Sex differences were determined based on color on abdominal sternite. The female insects have a pale yellow color on the fifth segment of its sternite and the male insects have brown color on all segments on its abdominall sternite (Hagstrum \& Subramanyam, 2006) .

\section{Determination of Cereals Susceptibility}

The susceptibility of cereal grains was determined by susceptible index method (Dobie, 1974) which is based on the number of $F_{1}$ progeny and the median development time of $R$. dominica. The amount of $F_{1}$ progeny was determined after 40 days of infestation. The adults were removed at 41 days after infestation and they were calculated daily until the whole progeny was calculated. The calculation of the median development time was observed daily, 23 days after infestation until $50 \%$ of new insects appeared (from the previous insects infested). The level of grain susceptibility can be categorized as resistant (range 0-3), moderate (range 4-7), susceptible (range 8-10), and very susceptible (range $>11$ ). This susceptibility index was calculated using the following formula (Dobie, 1974).

$$
\text { Susceptibility Index }=100 \times \frac{\left(\log _{e} F\right)}{D}
$$

Where:

$F=$ number of $F_{1}$ progeny

$\mathrm{D}$ = median development time

\section{Determination of Quantitative Damage}

Quantitative damage was observed by calculating the damaged cereals and the frass resulted from the damaged cereals. These damaged cereals were used in determining the level of damages due to the feeding activities of $R$. dominica. The calculation of damaged cereals was carried out on a sample of 100 grains and its percentage was calculated using a formula percentage of damaged cereals $=$ number of damaged cereals/number of samples) $x$ $100 \%$.

Frass results from damaged cereals caused by the feeding activities of $R$. dominica. To calculate the frass production, each type of cereal had to be sieved to separate the damaged cereals and its frass. The frass then was weighed and calculated, using the formula percentage of frass production $=$ (weight of frass/weight of grains initial) x 100\% (Hendrival \& Muetia, 2016). 


\section{Data analysis}

The research has been assigned in Completely Randomized Design (CRD), using different kind of cereals: sorghum, wheat, corn, rice grain, white rice, white glutinous rice, and black glutinous rice. Each treatment was replicated three times. There were 21 experimental units. The data recorded in these experiments were subjected to Analysis of Variance and the means were compared using Duncan's Multiple Range Test (DMRT) at 0.05 probability level. The coefficient of correlation between different parameters was determined by correlation analysis.

\section{RESULTS AND DISCUSSIONS}

\section{Number of $F_{1}$ progeny}

Types of cereal had a great significant on the number of progeny produced by parental adults $\left(F=169.01^{* *} ; \mathrm{df}=6 ; \mathrm{P}\right.$ $<0.0001)$. The highest number of progeny found in wheat reached up to 1022.33 adult progeny which varied significantly in between other cereals. The number of adult progeny in black glutinous rice was 343.33 adults. On the contrary, there was no significant difference between corn, rice grains, sorghum, white rice, and white glutinous rice. The lowest number of insect population was found in white rice $(84.67$ adult) was followed by white glutinous rice (73.33 adult) (Table 1).

Rhyzopertha dominica has a high preference in all types of cereals. From the data, it can be said that wheat is the most preferred by this insect pest compared to other types of cereals. The different types of cereal grains can affect the number of progeny which influenced by the quality of cereals. The quality of cereals which measured by both physiological and chemical properties has the impact in the development of insect. The appropriate nutritional content in cereals can increase the amount of progeny production (Arthur et al., 2012). Toews et al. (2001) suggested that physical and chemical parameters of seeds can strongly influence the progeny of R. dominica. Astuti et al. (2013) showed that the physico-chemical characteristics of milled rice varieties are the effective factor on the development of $R$. dominica.

Table 1. Number of $F_{1}$ progeny, median development time, susceptibility index and category of cereal grains

\begin{tabular}{lcccl}
\hline \multicolumn{1}{c}{ Cereals } & $\begin{array}{c}\text { Number of } \\
\text { progeny } \\
\text { (adults/100 g) }\end{array}$ & $\begin{array}{c}\text { Median } \\
\text { Development } \\
\text { time (days) }\end{array}$ & $\begin{array}{c}\text { Susceptibility } \\
\text { Index }\end{array}$ & $\begin{array}{c}\text { Categories } \\
\text { susceptibility }\end{array}$ \\
\hline Sorghum & $121.67 \mathrm{c}$ & $38.00 \mathrm{c}$ & $5.49 \mathrm{~d}$ & Moderate \\
Wheat & $1022.33 \mathrm{a}$ & $32.67 \mathrm{f}$ & $9.21 \mathrm{a}$ & Susceptible \\
Corn & $160.33 \mathrm{c}$ & $36.00 \mathrm{~d}$ & $6.12 \mathrm{c}$ & Moderate \\
Rice grains & $146.33 \mathrm{c}$ & $37.33 \mathrm{c}$ & $5.80 \mathrm{~cd}$ & Moderate \\
White rice & $84.67 \mathrm{c}$ & $41.00 \mathrm{~b}$ & $4.69 \mathrm{e}$ & Moderate \\
White glutinous rice & $73.33 \mathrm{c}$ & $42.33 \mathrm{a}$ & $4.40 \mathrm{e}$ & Moderate \\
Black glutinous rice & $343.33 \mathrm{~b}$ & $34.67 \mathrm{e}$ & $7.27 \mathrm{~b}$ & Moderate-susceptible \\
\hline
\end{tabular}

Means in the same column followed by same letters do not differ significantly $(P=0.05)$ as determined by DMRT

\section{Median Development Time}

The results of the variance analysis showed that the different types of cereals had a very significant effect on the development time of $R$. dominica $(\mathrm{F}=$ $\left.72.97^{* *}, \mathrm{df}=6, \mathrm{P}<0.0001\right)$. The shortest median time found in wheat (32.67 days) and it was different from other types of 
cereals respectively. The median time in black glutinous rice and corn reached 34.67 and 36 days which were also significantly different from other cereals, whereas in rice and sorghum it reached 37.33 and 38 days. The longest median time was found in white rice and white glutinous rice, which were up to 41 and 42.33 days (Table 1 ).

These median development times described the compatibility between $R$. dominica and cereals. These data also illustrated the development of the egg becoming adults, in other hands, its life cycle. The life cycle of this insect was found in this study ranged from 32.67 to 42.33 days. These results were in corroboration with Edde (2012) who revealed that the life cycle of $R$. dominica ranged from 25-65 days. Shorter development time in cereals also indicates that the cereals are becoming more susceptible to $R$. dominica.

Table 2. Correlation coefficient between number of $F_{1}$ progeny, median development time, percentage of cereals weight and index susceptibility

\begin{tabular}{lccccc}
\hline \multicolumn{1}{c}{ Parameters } & $\begin{array}{c}\text { Number of } \mathrm{F} 1 \\
\text { progeny }\end{array}$ & $\begin{array}{c}\text { Median } \\
\text { development } \\
\text { time }\end{array}$ & $\begin{array}{c}\text { Percentage of } \\
\text { damaged } \\
\text { cereals }\end{array}$ & $\begin{array}{c}\text { Percentage of } \\
\text { frass } \\
\text { production }\end{array}$ & $\begin{array}{c}\text { Susceptibility } \\
\text { index }\end{array}$ \\
\hline $\begin{array}{l}\text { Number of } \mathrm{F}_{1} \text { progeny } \\
\begin{array}{l}\text { Median development } \\
\text { time }\end{array}\end{array}$ & $\begin{array}{c}1 \\
-0.768^{*}\end{array}$ & 1 & & & \\
$\begin{array}{l}\text { Percentage of } \\
\text { damaged cereals }\end{array}$ & $0.926^{* *}$ & $-0.888^{* *}$ & 1 & & 1 \\
$\begin{array}{l}\text { Percentage of frass } \\
\text { production }\end{array}$ & $0.951^{* *}$ & $-0.852^{* *}$ & $0.993^{* *}$ & & \\
Susceptibility index & $0.933^{* *}$ & $-0.942^{* *}$ & $0.977^{* *}$ & $0.971^{* *}$ & 1 \\
\hline
\end{tabular}

** Significant at $1 \%$ level * significant at $5 \%$ level

\section{Susceptibility Index of cereals}

The results showed that different cereals exhibited significant susceptibility after being infested by $R$. dominica $(F=$ 157.58**, df $=6, P<0.0001)$. The susceptibility index of cereals tested ranged from 4.40 to 9.21 . The highest susceptibility index was exposed by wheat respectively (9.21), followed by black glutinous rice (7.27), rice grain (5.80) and sorghum (5.49) meanwhile the lowest index were found in white rice (4.69) and white glutinous rice (4.40). From these results, it can be concluded that wheat was susceptible, while sorghum, corn, white rice and white glutinous rice was considered moderate and black glutinous rice was moderate-susceptible to infestation of $R$. dominica (Table 1 ).
The susceptible or moderate to susceptible cereals such as wheat and black glutinous rice have an attraction for imago $R$. dominica to lay eggs and breed, while moderate cereals may be less favored because they produce antibiotic compounds. Keba \& Sori (2013) suggested that corn genotype the susceptible have an attraction to insects for lay eggs and breed. While the genotype resistant to the possibility of producing compounds that are of a nature antibiosis and nonpreference as a resistance mechanism. Saad et al. (2018) suggested that resistance of wheat against $R$. dominica and S. oryzae influenced by physical and chemical factors that are toxic to both insects.

The coefficient correlation results indicated a positive correlation between 
susceptibility index and number of $F_{1}$ progeny, a percentage of damaged cereals and percentage of frass production. There was also a negative correlation between susceptibility index and median development time of $R$. dominica. These findings revealed that number of $F_{1}$ progeny has increased the susceptibility index $\left(r=0.933^{* *} \quad P<0.01\right)$, median development time $(r=-0.942 * * P<0.01)$, percentage of damaged cereals $(r=$ $0.977^{* *} P<0.01$ ), and percentage of frass production ( $r=0.971^{* *} P<0.01$ ) (Table 2$)$. It can be said that the factors mentioned above could be an indicator to measure the cereal susceptibility. Abebe et al. (2009) have considered median development time and percentage of damaged cereals as an indicator to evaluate corn susceptibility to Sitophilus zeamais.

Susceptibility of cereals to $R$. dominica can be also determined by the small number of populations and longer development time (Goftishu \& Belete, 2014). The research done by Astuti et al. (2013) reported that the susceptibility of different varieties of rice plants influenced by number of $F_{1}$ progeny and median development time of $R$. dominica. They found that the abundance of $F_{1}$ progeny and short development time of this pest have caused rice plants very susceptible.

The increase of F1 progeny which followed by the increase of damage of cereals resulted in increasing susceptibility index and shorter development time which caused the commodities are susceptible to stored-product pest $R$. dominica. Shafique \& Chaudry (2007) suggested that a low number of progeny appears in cereal grains which followed by lower damage can be attributed as resistant grains against stored product pests.

\section{The Damage of Cereal Grains}

The results given in Table 2 described that different kinds of cereals significantly influenced the damage caused by $R$. dominica $\left(F=44.65^{* *}, \mathrm{df}=6, P<0.0001\right)$ and percentage of frass production $(F=$ $\left.195.12^{* *}, \mathrm{df}=6, P<0.0001\right)$. This study found that this pest caused great damage and created frass from its feeding activities. The highest percentage of damaged cereals found in wheat (80.67\%) significantly. Black glutinous rice reached up to $55.67 \%$. The damage caused by $R$. dominica to stored corn was insignificant compared to rice grain. The lowest percentage was reached by white glutinous rice, non-significant compared to sorghum and white rice.

Table 3. The damage of cereal grains caused by $R$. dominica

\begin{tabular}{|c|c|c|}
\hline Cereal Grains & $\begin{array}{c}\text { Percentage } \\
\text { of damaged } \\
\text { cereals }\end{array}$ & $\begin{array}{c}\text { Percentage } \\
\text { of frass } \\
\text { production }\end{array}$ \\
\hline Sorghum & $12.67 \mathrm{de}$ & $0.61 \mathrm{de}$ \\
\hline Wheat & $80.67 \mathrm{a}$ & $6.95 \mathrm{a}$ \\
\hline Corn & $31.67 c$ & $1.61 \mathrm{c}$ \\
\hline Rice grain & $20.67 \mathrm{~cd}$ & $0.82 \mathrm{~d}$ \\
\hline White rice & $12.33 \mathrm{de}$ & 0.40 ef \\
\hline White glutinous rice & $9.33 \mathrm{e}$ & $0.29 \mathrm{f}$ \\
\hline Black glutinous rice & $55.67 b$ & $4.25 \mathrm{~b}$ \\
\hline
\end{tabular}

Means in the same column followed by same letters do not differ significantly $(P=0.05)$ as determined by DMRT.

The highest percentage of frass production was observed $6.95 \%$ respectively compared to other cereals tested, such as black glutinous rice (4.25\%), corn $(1.61 \%)$, rice grain $(0.82 \%)$ and sorghum $(0.61 \%)$. The lowest percentage was observed in white glutinous rice (0.29\%) and insignificant compared to white rice (Tabel 3). Percentage of 
damaged cereals and the percentage of frass production are the parameters applied to evaluate the level of damage of stored grains caused by stored product pests. The measurement of damaged cereals observed visually by observing the holes and cracks made by insects on the kernels. This parameter cannot be used as an indicator to measure hidden infestation. Hidden infestation is the activity done by the parental adult $R$. dominica by laying eggs and covering them with secretions from the mouth glands in the seeds. Powder fraction or frass is resulted from damaged cereals which become immensely crumbly during the storage period. The damage on stored product grains is called quantitative losses (Kumar, 2017; Nayak \& Daglish, 2018).

Rhyzopertha dominica is a destructive pest which attacks whole grains in storage. Larvae and adult stages of this pest attack the same cereals. The adults destroy the cereals by damaging cereals resulted in a large amount of frass production, while the larvae attack from the inside. Larvae and adults stages are highly destructive which cause greater damage to the stored commodities is than other pests do. The losses occur during the storage period could be the main cause of quality degradation. The damage to cereals can cause characteristics deterioration and contamination in food grains and it also declines the protein and carbohydrates level due to insect metabolic processes and the appearance of microbes.

\section{CONCLUSIONS}

The results of the study indicated that different kind of cereals tested in this research had different level of susceptibility, from moderate to susceptible infestation of $R$. dominica. Sorghum, corn, rice grain, white rice, and white glutinous rice were classified moderate, wheat was susceptible, and black glutinous rice was moderately susceptible. The highest losses of cereals which determined by the amount of damaged grains and frass production occurred in wheat, black glutinous rice, corn and rice grain while the lowest found in sorghum, white rice, and white glutinous rice.

\section{REFERENCES}

Abebe, F., Tefera, T., Mugo, S., Beyene, Y., $\&$ Vidal, S. (2009). Resistance of maize varieties to the maize weevil Sitophilus zeamais (Motsch.) (Coleoptera: Curculionidae). African Journal of Biotechnology, 8(21), 5937-5943. https://doi.org/10.4314 /ajb.v8i21.66077

Ahmedani, M.S., Haque, M.I., Afzal, S.N., Aslam, M., \& Naz, S. (2009). Varietal changes in nutritional composition of wheat kernel (Triticum aestivum L.) caused by khapra beetle infestation. Pakistan Journal of Botany, 41(3), 1511-1519.

Ajaykumara, K.M., Thirumalaraju, G.T., \& Anjali, A.S. (2018). Seasonal variations in the biology of besser brain borer Rhyzopertha dominica (F.) (Coleoptera: Bostrychidae ) on btored baize under baboratory conditions. Journal of Entomology and Zoology Studies, 6(1), 516-522.

Arthur, F.H., Ondier, G.O., \& Siebenmor gen, T.J. (2012). Impact of Rhyzopertha dominica (F.) on quality parameters of milled rice. Journal of Stored Products Research, 48, 137142. 
https://doi.org/10.1016/j.jspr.2011.1 0.010

Astuti, L.P., Mudjiono, G., Rasminah, C.S., \& Rahardjo, B.T. (2013). Susceptibility of milled rice varieties to the lesser grain borer (Rhyzopertha dominica F). Journal of Agricultural Science, 5(2), 145-149. https://doi.org/10.5539 /jas.v5n2p145

Chanbang, Y., Arthur, F.H., Wilde, G.E., \& Throne, J.E. (2008). Hull characteristics as related to susceptibility of different varieties of rough rice to Rhyzopertha dominica (F.) (Coleoptera: Bostrichidae). Journal of Stored Products Research, 44(3), 205-212. https://doi.org /10.1016/j.jspr.2007.10.003

Chen, C.Y., \& Chen, M.E. (2013). Susceptibility of field populations of the lesser grain borer, Rhyzopertha dominica (F.), to deltamethrin and spinosad on paddy rice in Taiwan. Journal of Stored Products Research, 55, 124-127. https://doi.org/10.1016 /j.jspr.2013.10.001

Chougourou, D.C., Togola, A., Nwilene, F. E., Adeliossi, J., Bachabi, F., \& Oyetunji, O.E. (2013). Susceptibility of some rice varieties to the lesser grain borer, Rhyzopertha dominica Fab. (Coleoptera: Bostrichidae) in Benin. Journal of Applied Sciences, 13(1), 173-177. https://doi.org/10.3923 /jas.2013.173.177

Dobie, P. (1974). The laboratory assessment of the inherent susceptibility of maize varieties to post-harvest infestation by Sitophilus zeamais Motsch. (Coleoptera, Curculionidae). Journal of Stored Products Research, 10(3-4), 183-197. https://doi.org/10.1016/0022474X(74)90006-X
Edde, P.A. (2012). A review of the biology and control of Rhyzopertha dominica (F.) the lesser grain borer. Journal of Stored Products Research, 48, 1-18. https://doi.org/10.1016/j.jspr.2011.0 8.007

Edde, P.A., Phillips, T.W., \& Toews, M.D. (2005). Responses of Rhyzopertha dominica (Coleoptera: Bostrichidae) to its aggregation pheromones as influenced by trap design, trap height, and habitat. Environmental Entomology, 34(6), 1549-1557. https://doi.org/10.1603/0046-225x34.6.1549

Goftishu, M., \& Belete, K. (2014). Susceptibility of sorghum varieties to the maize weevil Sitophilus zeamais Motschulsky (Coleoptera: Curculioni dae). African Journal of Agricultural Research, 9(31), 2419-2426. https://doi.org/10.5897/AJAR2014.86 34

Hagstrum, D. W., \& Subramanyam, B. (2006). Fundamentals of StoredProduct Entomology. St. Paul, Minnesota USA: AACC International.

Hendrival, \& Muetia, R. (2016). Pengaruh periode penyimpanan beras terhadap pertumbuhan populasi Sitophilus oryzae (L.) dan kerusakan beras. Biogenesis: Jurnal IImiah Biologi, 4(2), 95-101 (Indonesian). https://doi.org /10.24252/bio.v4i2.2514

Keba, T., \& Sori, W. (2013). Differential resistance of maize varieties to maize weevil (Sitophilus zeamais Motschulsky) (Coleoptera: Curculionidae) under laboratory conditions. Journal of Entomology, 10(1), 1-12. https://doi.org/10.3923 /je.2013.1.12

Kumar, R. (2017). Insect pests of stored grain: Biology, behavior, and 
management strategies. In Insect Pests of Stored Grain: Biology, Behavior, and Management Strategies. https://doi.org/10.1201 /9781315365695

Mahroof, R.M., Edde, P.A., Robertson, B., Puckette, J.A., \& Phillips, T.W. (2010). Dispersal of Rhyzopertha dominica (Coleoptera: Bostrichidae) in different habitats. Environmental Entomology, 39(3), 930-938. https://doi.org/10.16 03/en09243

Nayak, M.K., \& Daglish, G.J. (2018). Importance of Stored Product Insects. In Recent Advances in Stored Product Protection (pp. 1-17). https://doi.org /10.1007/978-3-662-56125-6_1

Park, S., Arthur, F.H., Bean, S.R., \& Schober, T.J. (2008). Impact of differing population levels of Rhyzopertha dominica (F.) on milling and physicochemical properties of sorghum kernel and flour. Journal of Stored Products Research, 44(4), 322327. https://doi.org/10.1016/j.jspr. 2008.02.008

Perišić, V., Perišić, V., Vukajlović, F., Pešić, S., Predojević, D., Đekić, V., \& Luković, K. (2018). Feeding preferences and progeny production of Rhyzopertha dominica (Fabricius 1792) (Coleoptera: Bostrichidae) in small grains. BIOLOGICA NYSSANA, 9(1), 55-61. https://doi.org/10.5281/ zenodo.1470852

Saad, A.S.A., Tayeb, E.H.M., El-Shazli, M.M., \& Baheeg, S.A. (2018). Susceptibility of certain Egyptian and imported wheat cultivars to infestation by Sitophilus oryzae and Rhyzopertha dominica. Archives of Phytopathology and Plant Protection, 51(1-2), 14-29. https://doi.org/10.1080/03235408.20 18.1438779
Shafique, M., \& Chaudry, M.A. (2007). Susceptibility of maize grains to storage insects. Pakistan Journal of Zoology, 39(2), 77-81.

Toews, M.D., Cuperus, G.W., \& Phillips, T.W. (2000). Susceptibility of eight U.S. wheat cultivars to infestation by Rhyzopertha dominica. Environmental Entomology, 29(2), 250-255.

Toews, M.D., Phillips, T.W., \& Cuperus, G.W. (2001). Effects of wheat cultivar and temperature on suppression of Rhyzopertha dominica (Coleoptera: Bostrichidae) by the parasitoid Theocolax elegans (Hymenoptera: Pteromalidae). Biological Control, 21(2), 120-127. https://doi.org/10. 1006/bcon.2001.0926

Vardeman, E.A., Campbell, J.F., Arthur, F.H., \& Nechols, J.R. (2007). Behavior of female Rhyzopertha dominica (Coleoptera: Bostrichidae) in a monolayer of wheat treated with diatomaceous earth. Journal of Stored Products Research, 43(3), 297-301. https://doi.org/10.1016/j.jspr.2006.0 7.001 